\title{
Dating Status and Sociability as Predictors of Academic Performance among University Students
}

\author{
Phebe B. Awe \\ Department of Psychology, \\ Federal University, Oye-Ekiti, Nigeria \\ Elizabeth 0. Akinyemi \\ Department of Psychology, \\ Ekiti State University, Ado-Ekiti, Nigeria \\ Benjamin 0. Omolayo \\ Department of Psychology, \\ Federal University, Oye-Ekiti, Nigeria \\ Morakinyo 0. Balogun \\ Department of Counselling \& Human Development, \\ Federal University, Otuoke, Bayelsa, Nigeria
}

\begin{abstract}
Overtime, academic performance has been an area of interest in research in terms of looking at factors that influences academic performance. However, this study investigated dating status and sociability as predictors of academic performance among undergraduate students. A cross-sectional study was conducted in selected 8 Departments from 4 Faculties at Federal University Oye-Ekiti, Nigeria. A total of 200 participants were involved in the study comprising of 124 male and 76 female. A validated semi-structured questionnaire was used to investigate dating status and sociability while academic performance was based on students' CGPAs. The data were analysed using descriptive, chi-square, ANOVA and t-test for independent samples. Results showed that dating status has no significant influence on academic performance $(F=0.721, d f=199, p>.05)$ while sociability has a negative influence on academic performance $(t=2.046, d f=159, p<.05)$. Having reading/interacting friends have a significant relationship with academic performance $\left(x^{2}=16.930, p<.05\right)$. The study made an important contribution to the body of knowledge on dating status and sociability as predictors of academic performance
\end{abstract}

Keywords: Dating status, Sociability, Academic performance, Undergraduates, University students.

\section{INTRODUCTION}

Academic performance represents performance outcomes that indicate the extent to which a person has accomplished specific goals that were focus of activities in instructional environments specifically in schools, colleges and universities [2]. The social and economic development of a country is link directly with students' academic performance [6]. Students' performance plays an important role in producing best quality graduates who will become great leaders and work force for the country, thus responsible for the country's economic and social development [1]. A study conducted by [10] noted that education is one of the biggest achievements and the trademark on how individuals are recognized, not only at work, but also by people whom they meet in everyday life and the key in attainment of goals. It is generally known that people usually doff their caps to show respect when they come across a well- 
grounded scholar, and education happens to be the best legacy that could be given to a child in life. However, admission into university for a course of study is one of the steps to attain desired educational heights which could be used to secure a formal and decent employment. Although university life could involve stressful situation but it is one of the memorable experiences in life. It represents a critical developmental period for both late adolescents and young adults [4].

Dating is a human relationship process where two people agreed to companionship which goes beyond the level of friendship and with the aim of assessing the suitability as partner in an intimate relationship. Dating is an intimate relationship which involves romance and sexual but could be a stressor when the level of commitment becomes too much. At a minimum, romantic involvement is likely to require at least some investment of time and energy from the participants, but this can range up to a nearly all-consuming level of investment and due to these investments, dating potentially distracts students from other areas of their lives, most notably school [11]. Dating relationship negatively contributed to students' academic performance and their psychosocial functioning [15], [13]. It also has a negative relationship on academic performance [13]. [9] observed that being in an intimate relationship involve trust, sensitivity and responsiveness, been able to make a commitment, striving for equity and mutuality. For a student, it also means working to achieve academic balance. However, it is established that dating has a positive effect on emotional health of adolescents [16].

Sociability is the quality of liking to meet and spend time with other people [3]. Sociability is the play-form of association, that is, the pleasurable, joyful and delightful experience that comes out of people's interaction in the society [12]. Acquiring a sound knowledge is bedrock of higher academic performance as it involves interaction between students and lecturers and among students. However, students who display sociability traits could be prone to more opportunities for advancement in their academic performance because the traits can instil confidence in them. Moreover, this confidence encourages the students to mix freely and interact with people around them. A study conducted by [8] on personality characteristics as predictors of academic performance of secondary school students revealed that extraversion, under which sociability is found had a significant relationship with academic performance. A student who can easily mix and interact well with other students and lecturers usually finds it easy to contribute to class discussion or ask questions from lecturers and colleagues that have better understanding compared to a student who finds it difficult to relate with others. Such student may find it difficult in approaching anyone either lecturer or other students when faced with difficulties in academic.

\section{OBJECTIVES OF THE STUDY}

The objectives of this study are:

i. To assess the level at which dating status will predict academic performance among undergraduate students.

ii. To know the influence of sociability on academic performance among undergraduate students.

iii. To assess the level at which having reading friends could predict academic performance among undergraduate students.

\section{SIGNIFICANCE OF THE STUDY}

The study investigates the extent to which students' academic performance could be explained by dating status. Also, it gave an explanation whether sociability could predict academic performance. Moreover, the study investigates the influence of having reading/interacting friends on academic performance among undergraduate students. 


\section{HYPOTHESES}

1. Dating status will significantly predict academic performance among undergraduate students.

2. Sociability will significantly predict academic performance among undergraduate students.

3. Having reading/interacting friends will have a significant relationship with academic performance among undergraduate students.

\section{DESIGN}

The study was cross-sectional involving the use of a semi-structured questionnaire containing information on sociability and dating status of respondents.

\section{STUDY SETTING}

The study was carried out in Oye-Ekiti which is one of the 16 Local Government Areas of Ekiti State, South-West, Nigeria. Ekiti State is one of the 36 States in Nigeria. The State was carved out from the territory of old Ondo State in October, 1996. Oye-Ekiti is a medium-sized town with a population of about 134,210 inhabitants as at 2006 which was the last census conducted in Nigeria.

The study location was Federal University, Oye-Ekiti, founded in 2011 by the Federal Government of Nigeria. The University has two campuses located at Oye-Ekiti and Ikole-Ekiti. It has five Faculties namely Agriculture, Arts, Engineering, Science and Social Sciences, and thirty-one Departments with about 2, 500 students as at the time of this study. Federal University, Oye-Ekiti (FUOYE) is officially accredited and recognized by the National University Commission, Nigeria and it offers courses and programs leading to educational degrees such as Bachelor of Agriculture (B.Agric), Bachelor of Arts (B.A), Bachelor of Engineering (B.Eng) and Bachelor of Science (B.Sc) in several areas of studies. The faculties used for the study were Faculties of Agriculture, Engineering (located at Ikole-Ekiti campus), Sciences and Social Sciences (located at Oye-Ekiti campus).

\section{STUDY POPULATION}

The study population comprised of undergraduate students of Federal University, Oye-Ekiti in Ekiti State of Nigeria.

\section{INCLUSION AND EXCLUSION CRITERIA}

The study participants were 200 to 400 level undergraduate students of Federal University, Oye-Ekiti, Nigeria. 100 level undergraduate students of the university were excluded because they were yet to have a Cumulative Grade Point Average (CGPA) as at the time the study was conducted which is one of the instruments that was used to measure the variables.

\section{SAMPLE SIZE}

The estimated sample size was 240 undergraduate students but was reduced to 200 because many of the 400 level students in Faculties of Agriculture and Engineering were on Industrial Training as at the time the study was conducted.

\section{SAMPLING PROCEDURE}

A multi-stage random sampling procedure was used in this study.

First stage: Four Faculties were randomly selected by balloting from the existing five Faculties in the University. The selected Faculties are Agriculture, Engineering, Sciences and Social Sciences. 
Second stage: Two Departments were randomly selected by balloting from each of the selected Faculties to make a total number of eight Departments for the study. The selected Departments are Agricultural-Economics \& Extension, Water Resources, Civil Engineering, Computer Engineering, Mathematics, Computer Science, Psychology and Sociology.

Third stage: Ten participants were randomly selected by balloting from each level of the Department selected.

\section{STUDY INSTRUMENT}

The instrument used for this study was a self-constructed questionnaire comprising of three sections namely:

Section A: It consists of the socio-demographic information of the participants such as age, gender, level, faculty, department, campus location, religion and ethnic group.

Section B: It contains items that measure sociability. The Sociability scale is a 25 -item questionnaire measuring reading/interacting attitude and sociability developed by [5]. Items 1-7 measure attitude towards keeping friends, items 8, 11, 12 \& 13 measure gender sensitivity in friendship making, items 9 \&10 measure attitudinal consistency in keeping friends, items 14-21 measure group membership and social behaviour while items 22-25 measure profile self-evaluation. The scale has a coefficient of $r=0.76$ for error variance of time, a coefficient of $r=0.86$ for error variance of content, and a coefficient of $r=0.87$ for error variance of homogeneity as reliability coefficients while it has a criterion validity coefficient of $r=0.25$. Questions 1, 3-9 were adapted from the Sociability Scale [5] to suit the research findings on having reading/interacting friends.

Section C: In order to measure dating status, a valid ordinary questionnaire item was used. This single questionnaire item does not need to meet up with requirement of validity.

\section{PROCEDURE}

Approval was gotten from the necessary University Officers including the Registrar, Heads of Departments, Dean of Students' Affairs and Academic Affairs Office to allow for easy access to the students' CGPA. Participants' consent was also obtained before the commencement of the study.

The students' academic performances were assessed based on the following grades:

i. First class division (4.50-5.00) - Excellent - High performance

ii. Second class, Upper division (3.50-4.49) - Very Good - High performance

iii. Second class, Lower division (2.40-3.49) - Averagely Good - Average performance

iv. Third class (1.50-2.39) - Below Average - Below average performance

v. Pass (1.00-1.49) - Low performance - Low performance

vi. Fail (0.00-0.90) - Fail - Poor performance

\section{STATISTICAL ANALYSES}

Data collected were analysed using the Statistical Package for Social Science (SPSS) version 17. Descriptive statistics such as frequency, mean, standard deviation, and variance was conducted to describe the socio-demographic information of the participants. Some categorical data were presented as charts. Chi-square test was utilized to check the relationship between the dependent and independent variables, Analysis of Variance (ANOVA) was used to compare the difference in mean scores of continuous variable and t-test for independent samples was also used to test for the research hypotheses. 


\section{ETHICAL CONSIDERATION}

Letter of approval was obtained from the University Registrar. Participants were informed of the purpose of study and assured of confidentiality. Consent forms were given to the participants to read and to sign in agreement to participate in the study before the distribution and filling of the questionnaires. They were also given the freedom to accept or decline participation in the study with no penalty attached.

\section{RESULTS}

Table I: Demographic information of participants

\begin{tabular}{lc}
\hline Variable & N (\%) \\
\hline Gender & $124(63.0)$ \\
Male & $76(38.0)$ \\
Female & \\
Level of study & \\
200 level & $80(40.0)$ \\
300 level & $80(40.0)$ \\
400 level & $40(20.0)$ \\
Faculty & \\
Social Sciences & $60(30.0)$ \\
Engineering & $40(20.0)$ \\
Science & $60(30.0)$ \\
Agriculture & $40(30.0)$ \\
Social Science & \\
Psychology & $100(50.0)$ \\
Sociology & $100(50.0)$ \\
Campus location & \\
Oye-Ekiti & $120(60.0)$ \\
Ikole-Ekiti & $80(40.0)$ \\
Religion Affiliation & \\
Christian & $177(88.5)$ \\
Muslim & $22(11.0)$ \\
Non response & $1(0.5)$ \\
Ethnic Group & \\
Hausa & $6(3.0)$ \\
Yoruba & $24(12.0)$ \\
Non response & $37(83.5)$ \\
\hline & \\
& \\
&
\end{tabular}


Table II: Participants' responses to sociability questions

\begin{tabular}{|c|c|c|c|c|c|c|}
\hline \multirow[t]{2}{*}{ Variable } & \multicolumn{2}{|l|}{ Yes } & \multicolumn{2}{|l|}{ No } & \multicolumn{2}{|c|}{$\begin{array}{l}\text { No } \\
\text { response }\end{array}$} \\
\hline & $\mathrm{N}$ & $\%$ & $\mathrm{~N}$ & $\%$ & $\mathrm{~N}$ & $\%$ \\
\hline Problem of relating with friends & 169 & $(84.5)$ & 30 & $(15.0)$ & 1 & $(0.5)$ \\
\hline Opposite sex friends & 171 & $(85.5)$ & 26 & $(13.0)$ & 3 & (1.5) \\
\hline Opposite sex more than same sex-friends & 76 & $(38.0)$ & 121 & $(60.5)$ & 3 & $(1.5)$ \\
\hline Team/group member & 172 & $(86.0)$ & 26 & $(13.0)$ & 2 & $(1.0)$ \\
\hline Good reading/interacting group & 150 & $(75.0)$ & 45 & $(22.5)$ & 5 & $(2.5)$ \\
\hline $\begin{array}{l}\text { Having reading friends in your } \\
\text { Department }\end{array}$ & 124 & $(62.0)$ & 72 & $(36.0)$ & 4 & $(2.0)$ \\
\hline Department's friend a close friend & 134 & $(67.0)$ & 65 & $(32.5)$ & 1 & $(0.5)$ \\
\hline Having friends in your department & 190 & $(95.0)$ & 10 & $(5.0)$ & 0 & 0 \\
\hline $\begin{array}{l}\text { Keeping a reading/interacting friendship for a } \\
\text { long time }\end{array}$ & 155 & $(77.5)$ & 45 & $(22.5)$ & 0 & 0 \\
\hline Ever Keeping the kind of friendship mentioned & 150 & $(75.0)$ & 48 & $(24.0)$ & 2 & $(1.0)$ \\
\hline $\begin{array}{l}\text { Long-time reading/interactive friend same sex } \\
\text { with you }\end{array}$ & 127 & $(63.5)$ & 65 & $(32.5)$ & 8 & $(4.0)$ \\
\hline Closeness to reading/interacting friends & 143 & $(71.5)$ & 50 & $(25.0)$ & 7 & $(3.5)$ \\
\hline Good reading/interacting group & 150 & $(75.0)$ & 45 & $(22.5)$ & 5 & $(2.5)$ \\
\hline important to be a leader & 149 & $(74.5)$ & 51 & $(25.5)$ & 0 & 0 \\
\hline Been in a formally organized social group & 154 & $(77.0)$ & 45 & $(22.5)$ & 1 & $(0.5)$ \\
\hline Presently belong to a formally organized group & 115 & $(57.5)$ & 84 & $(42.0)$ & 1 & $(0.5)$ \\
\hline Been expelled from a social group & 194 & $(97.0)$ & 4 & $(2.0)$ & 2 & $(1.0)$ \\
\hline Loyal in my group & 180 & $(90.0)$ & 12 & $(6.0)$ & 8 & $(4.0)$ \\
\hline Possesses any of the social characteristics & 168 & $(84.0)$ & 15 & & 17 & \\
\hline
\end{tabular}


Table III: Testing the influence of dating status on academic performance (CGPA) using

\section{Descriptive} ANOVA.

\begin{tabular}{|c|c|c|c|c|c|c|}
\hline & \multirow[b]{2}{*}{$\mathrm{N}$} & \multirow[b]{2}{*}{ Mean } & \multirow[b]{2}{*}{ Std. Deviation } & \multirow[b]{2}{*}{ Std. Error } & \multicolumn{2}{|c|}{$\begin{array}{l}95 \% \text { Confidence Interval for } \\
\text { Mean }\end{array}$} \\
\hline & & & & & Lower Bound & Upper Bound \\
\hline open relationship & 77 & 2.8918 & .90862 & 10355 & 2.6856 & 3.0981 \\
\hline serious relationship & 68 & 2.7056 & .86505 & . 10490 & 2.4962 & 2.9150 \\
\hline same sex relationship & 6 & 2.6400 & 1.00373 & .40977 & 1.5866 & 3.6934 \\
\hline others & 49 & 2.8827 & .83878 & .11983 & 2.6417 & 3.1236 \\
\hline Total & 200 & 2.8187 & .87788 & .06208 & 2.6963 & 2.9411 \\
\hline
\end{tabular}

\section{ANOVA}

$$
\text { CGPA }
$$

\begin{tabular}{|l|l|l|l|l|l|}
\hline & $\begin{array}{l}\text { Sum of } \\
\text { Squares }\end{array}$ & df & Mean Square & F & Sig. \\
\hline Between Groups & 1.674 & 3 & .558 & .721 & .541 \\
Within Groups & 151.690 & 196 & .774 & & \\
Total & 153.364 & 199 & & & \\
\hline
\end{tabular}

From Table III the Analysis of Variance (ANOVA) shows that the means difference of CGPA among the groups $(\mathrm{F}=0.721, \mathrm{df}=199, \mathrm{p}>.05)$ is not significant. Therefore, hypothesis 1 is rejected.

Table IV: Testing for sociability variables using independent t-test

\section{Group Statistics}

\section{CGPA}

\begin{tabular}{|l|l|l|l|l|}
\hline $\begin{array}{l}\text { Social } \\
\text { Characteristics }\end{array}$ & $\mathrm{N}$ & Mean & $\begin{array}{l}\text { Std. } \\
\text { Deviation }\end{array}$ & $\begin{array}{l}\text { Std. Error } \\
\text { Mean }\end{array}$ \\
\hline No & 15 & 3.3320 & .78641 & .20305 \\
Yes & 146 & 2.8692 & .83864 & .06941 \\
\hline
\end{tabular}

Independent Samples Test

\begin{tabular}{|c|c|c|c|c|c|}
\hline & \multicolumn{2}{|c|}{$\begin{array}{l}\text { Levene's Test for Equality } \\
\text { of Variances }\end{array}$} & \multicolumn{2}{|c|}{$\begin{array}{l}\text { t-test for Equality of } \\
\text { Means }\end{array}$} \\
\hline & & $\mathrm{F}$ & Sig. & $t$ & Df \\
\hline \multirow[t]{2}{*}{ CGPA } & $\begin{array}{l}\text { Equal variances } \\
\text { assumed }\end{array}$ & 195 & .660 & 2.046 & 159 \\
\hline & $\begin{array}{l}\text { Equal variances not } \\
\text { assumed }\end{array}$ & & & 2.157 & 17.440 \\
\hline
\end{tabular}


Independent Samples Test

\begin{tabular}{|c|c|c|c|c|}
\hline & & \multicolumn{3}{|c|}{ t-test for Equality of Means } \\
\hline & & Sig. (2-tailed) & $\begin{array}{l}\text { Mean } \\
\text { Difference }\end{array}$ & $\begin{array}{l}\text { Std. Error } \\
\text { Difference }\end{array}$ \\
\hline \multirow[t]{2}{*}{ CGPA } & $\begin{array}{l}\text { Equal variances } \\
\text { assumed }\end{array}$ & .042 & .46282 & .22618 \\
\hline & $\begin{array}{l}\text { Equal variances not } \\
\text { assumed }\end{array}$ & .045 & .46282 & .21459 \\
\hline
\end{tabular}

From Table 4, results shows that sociability have negative significant influence on academic performance $(\mathrm{t}=2.046 ; \mathrm{df}=159, \mathrm{p}<.05)$.

Table V: Tests of relationship between academic performance and some variables using chisquare

\begin{tabular}{lrll}
\hline Variables & \multicolumn{1}{c}{2} & P-value & Status \\
\hline Dating status & 13.937 & 0.530 & Not significant \\
Opposite sex friend & 3.577 & 0.612 & Not significant \\
Opposite sex more than same sex friends & 6.355 & 0.273 & Not significant \\
Team/group member & 2.776 & 0.734 & Not significant \\
Good reading/interacting group & 5.243 & 0.387 & Not significant \\
Having friends in your department & 12.236 & 0.032 & Significant \\
Keeping a reading/interacting friendship & 16.930 & 0.005 & Significant \\
for long & & & \\
Kind of friendship & 12.181 & 0.032 & Significant \\
Place of keeping reading/interacting & 1.427 & 0.921 & Not significant \\
friendship & 5.975 & 0.309 & Not significant \\
Possesses Social Characteristics & 5.655 & 0.843 & Not significant \\
Degree of Social Characteristics & & & \\
\hline
\end{tabular}

Table $\mathrm{V}$ shows that sociability in terms of having reading and interacting friends have a relationship with students' academic performance while dating status and possession of other social characteristics do not have significant relationship with students' academic performance. 
Table VI: Table showing the academic performance of the participants

\begin{tabular}{ll}
\hline Variables & $\mathbf{N}(\%)$ \\
\hline Class & \\
First class & $1(0.5)$ \\
& 48 \\
Second class Upper division & $(24.0)$ \\
& 87 \\
Second class Lower division & $(43.5)$ \\
Third class & $43(21.5)$ \\
Pass & $19(9.5)$
\end{tabular}

Table VI reveals that only one student has a CGPA of between 4.50 and 5.00 (First class division), 87 has Second Class Lower Division, and 2 of them have less than 1.0 in their CGPA.

Figure I: Bar chart showing respondents responses to question on dating status

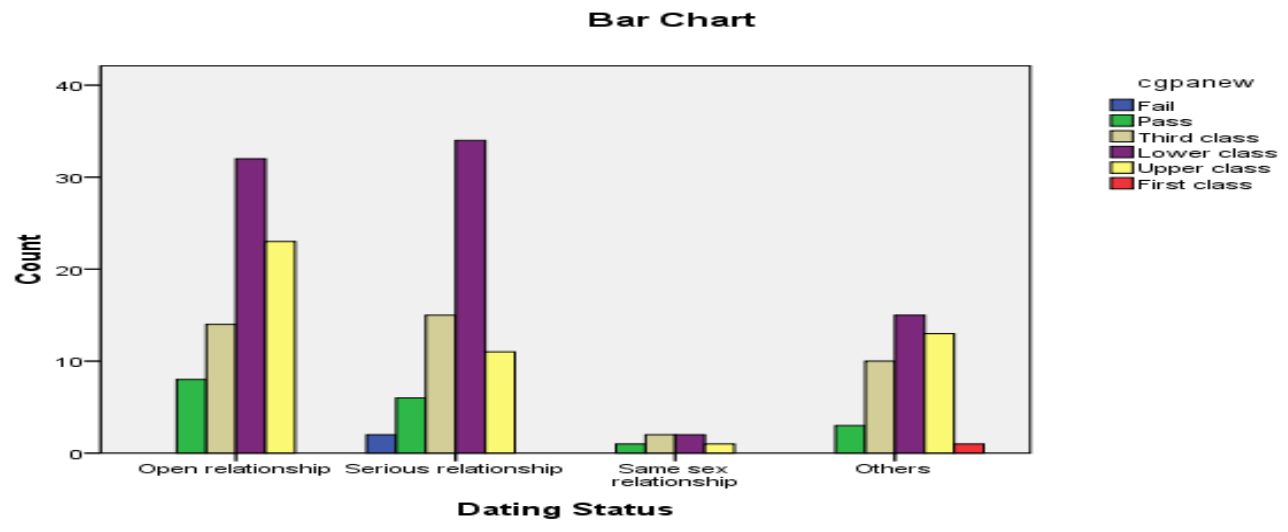

Figure I above show respondents' responses to questions on dating status and they are grouped according to the division of CGPA.

Figure II: Bar chart showing respondents responses to Being an Active Team/Group Member.
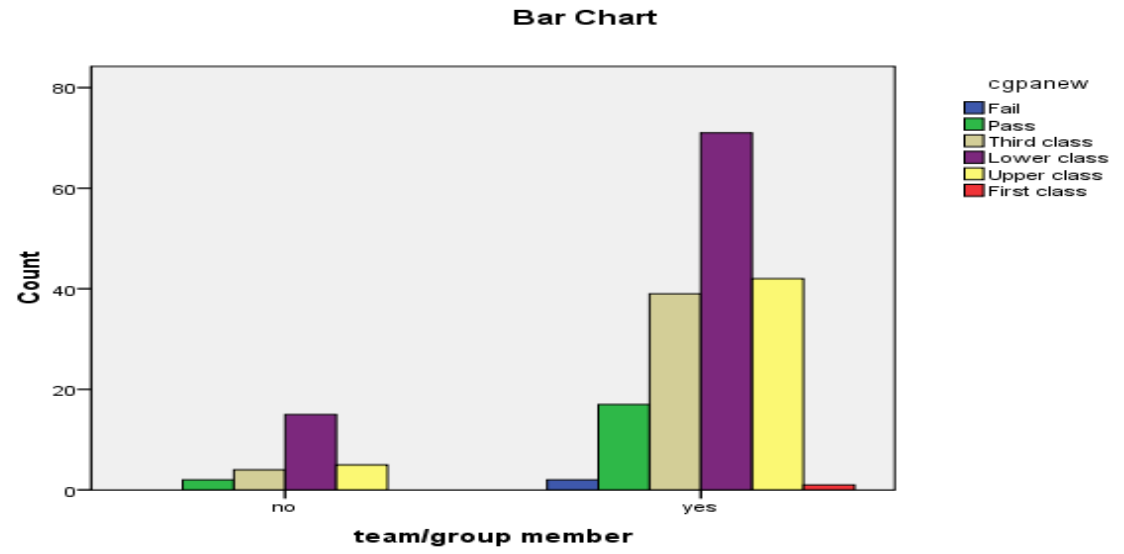

Figure II shows respondents responses to question on being an active team/group member in any academic group work they are assigned to, and the chart reveals the category the respondents belong to and their divisional CGPA. 
Figure III: Bar chart showing respondents responses to Having Reading/Interacting Group

\section{Bar Chart}

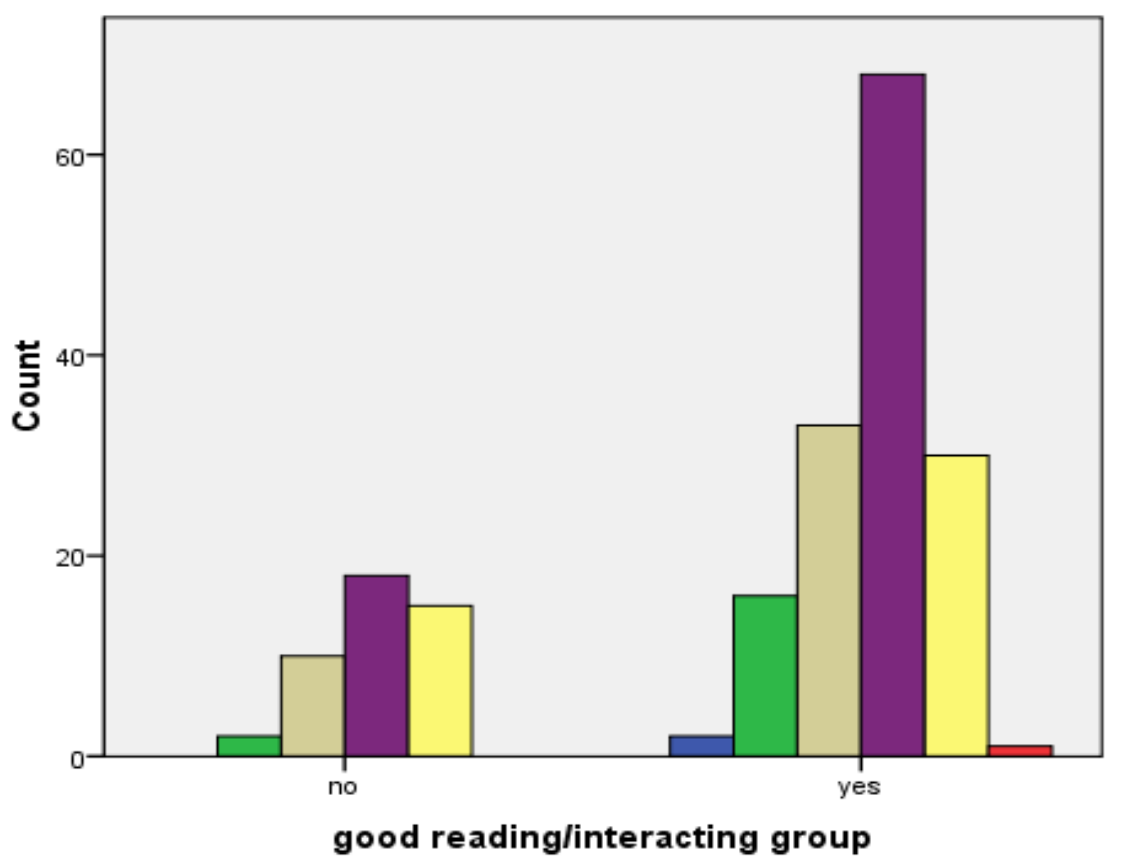

cgpanew

口ail

$\square$ Pass

Third class

Lower class

Dupper class

First class

Figure III shows respondents responses to question on having good reading/interacting group; it reveals the category that the respondents fall in and their division of CGPA.

Figure IV: Bar chart showing respondents responses to questions on Having Friends in the Same Department

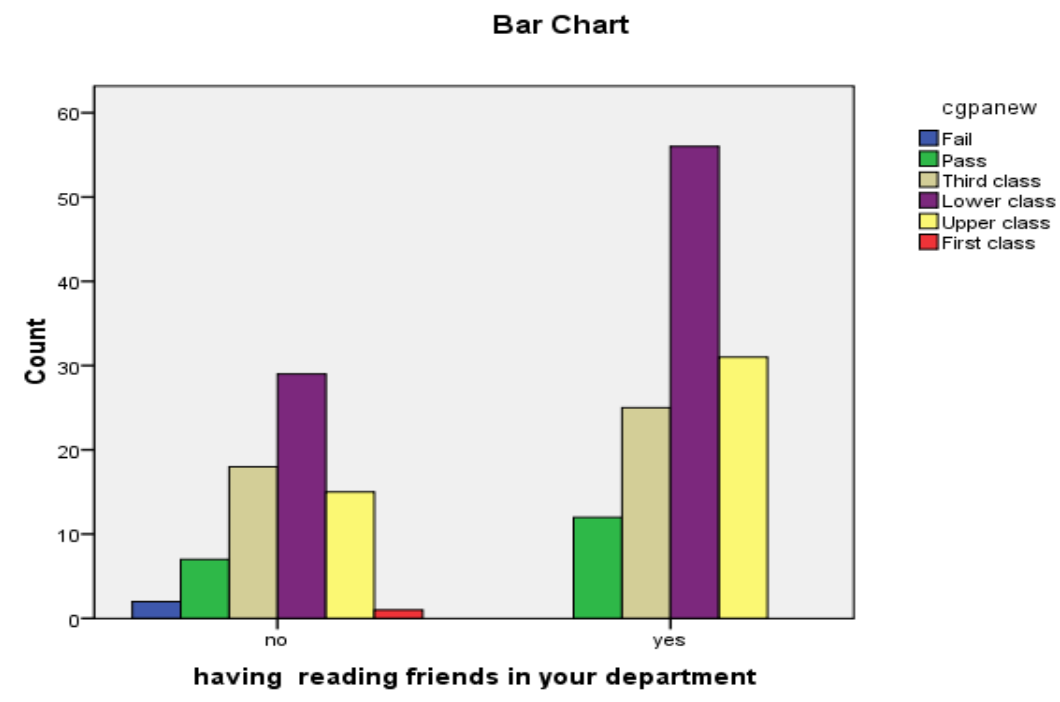

Figure IV shows respondents responses to question on having reading friends in their departments. It reveals the category they belong and their division of CGPA. 


\section{Figure V: Bar chart showing respondents responses to Having Social Characteristics}

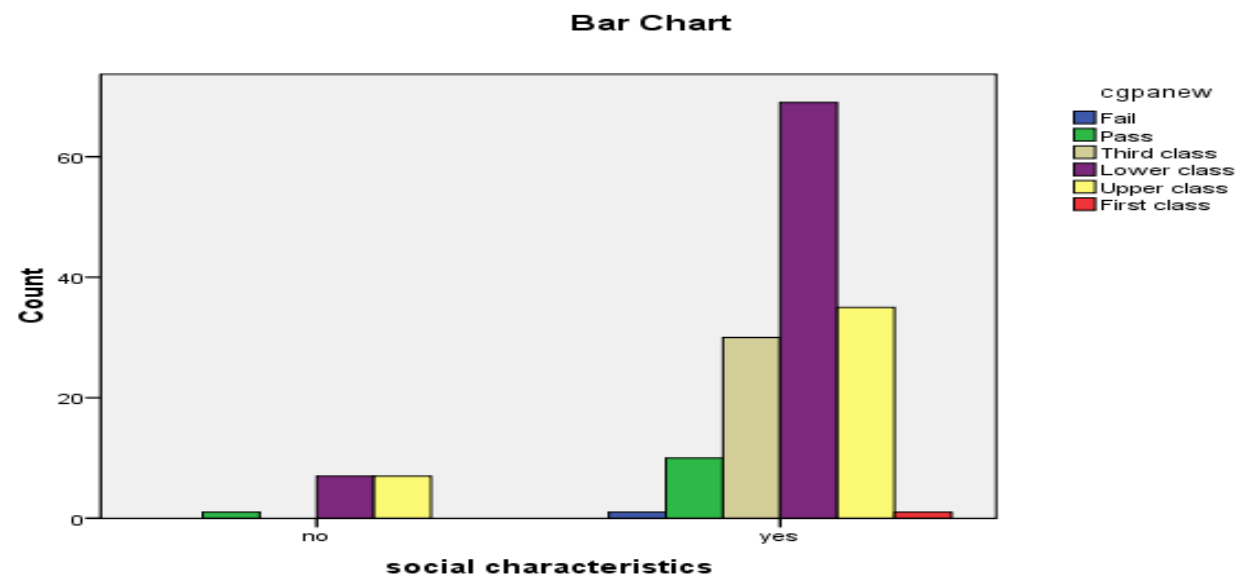

Figure $\mathrm{V}$ shows respondents responses to question on some social characteristics such as having ability to mix freely with people, entertaining, outgoing, and spontaneously friendly; the chart also reveals the category the respondents belong and their division of CGPA.

\section{Figure VI: Bar chart showing respondents responses to Possession of Social Characteristics}

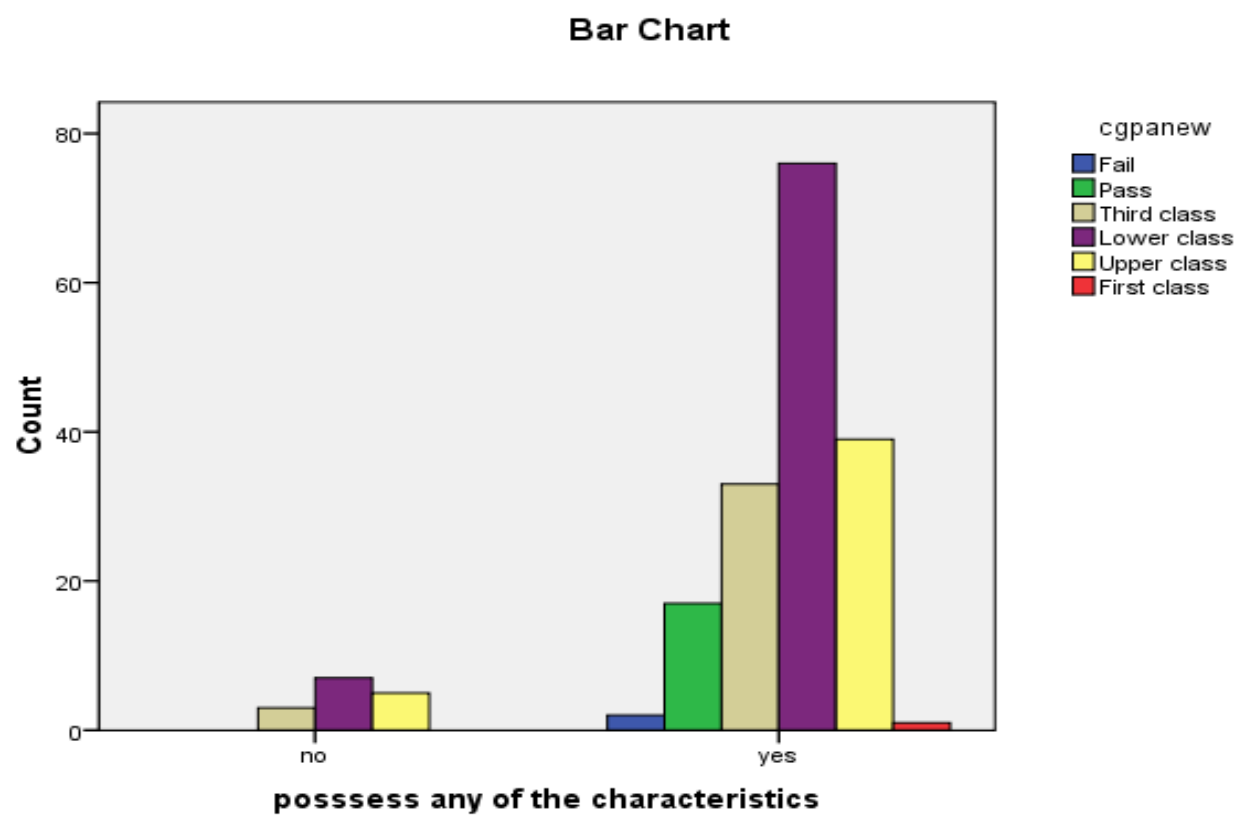

Figure VI shows the respondents' responses to question on possession of social characteristics, the chart is still in support of figure 4.2 .5 above; it also reveals the category that the respondents belong and the division of their CGPA. 


\section{Figure VII: Bar chart showing respondents' responses to questions on the Degree to Which They} Possess Social Characteristics

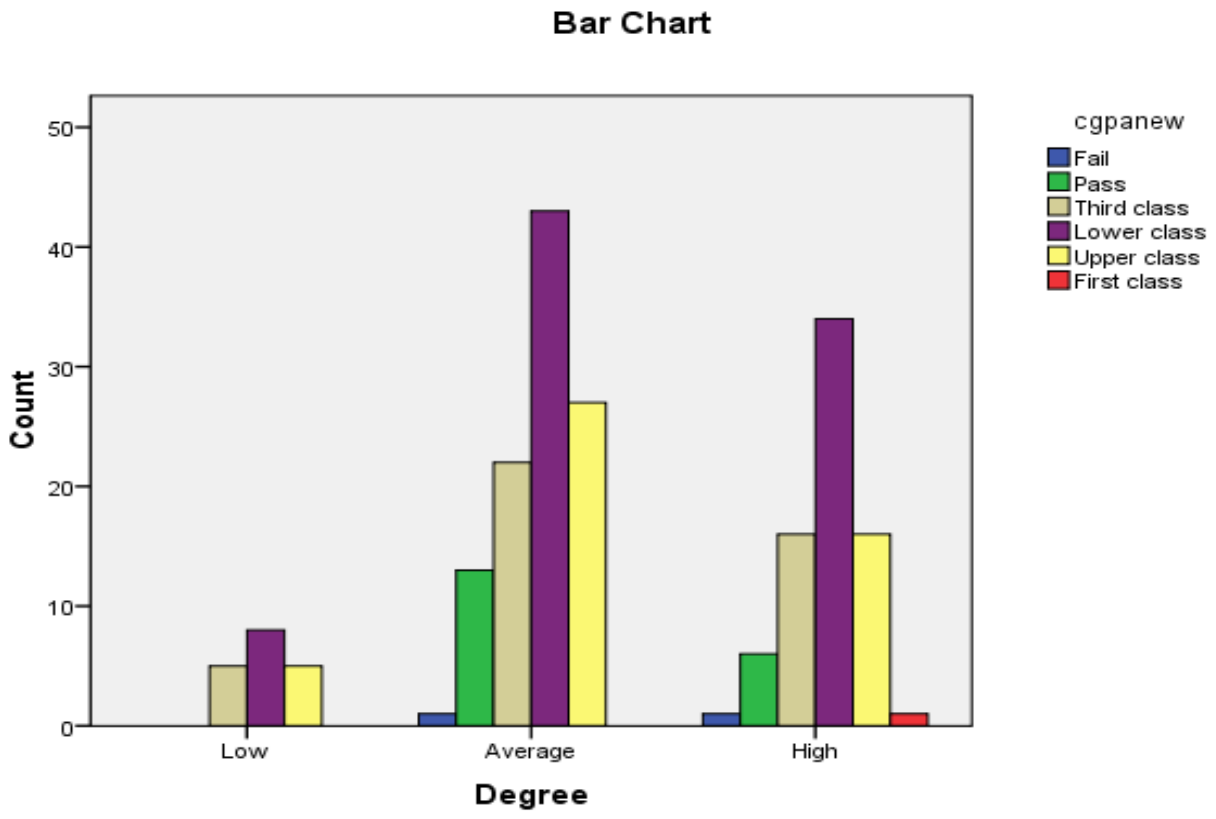

Figure VII shows the respondents' responses to question on the degree to which they possess social characteristics; it reveals the category they belong and the division of their CGPA.

\section{DISCUSSION}

Findings from this study showed that dating status does not have influence on academic performance. The plausible interpretation of this finding is that irrespective of the dating status of a student, his/her academic performance is not affected by it. This is in support of previous studies of [7] who concluded in his finding that there was no impact of romantic relationship on student's GPA. However, the previous findings of [10] and [15] that having a relationship affect academic performance differs from the findings of this study.

Furthermore, result from this study revealed that sociability have negative significant influence on academic performance, which means those who do not have social characteristics have higher academic performance than those who have social characteristics. This does not support [14] who concluded having high level of sociable characteristics leads to attaining high academic achievement in educational situation. However, [8] revelation that extraversion had a significant relationship with academic performance tends to agree with the result of this study.

It was also found in this study that having reading/interacting friends have a significant relationship with academic performance among undergraduate students. It can therefore be relayed that if a person could channel his/her social characteristics to keeping friends that would assist, help and impart more knowledge to his/her educational life, it could yield a positive and higher academic performance, unlike those that only enjoy being in company of others jesting and going out without any useful positive contribution to their academic performance.

\section{LIMITATIONS OF THE STUDY}

The limitation of this study is that participants were limited to few departments in the university. 


\section{CONCLUSION AND RECOMMENDATION}

The findings from this study showed that dating status have no significant influence on academic performance of undergraduate students. Also sociability has a negative impact on academic performance of undergraduate students but having reading/interacting friends have a significant relationship on academic performance. Therefore, there is need to educate the students more on having reading/interacting friends so as to improve their academic performance during their stay in the university.

\section{References}

Ali, N., Jusoff, K., Ali, S., Mokhtar, N., \& Salamt, A. S. (2009). The factors influencing students performance at University Teknologi, MARA Kedah, Malaysia. Canadian Research \& Development Centre of Sciences and Cultures, $3(4)$.

Ali, S., Zubair, H., Fahad, M., Hamid, K., \&Awais, A., (2013). Factors contributing to students' academic performance in Islamia University Sub-campus. American Journal of Educational Research, 18, 283-287.

Cambridge Dictonary (2016). Sociability. In Cambridge Dictonary retrieved from http:/dictionary.cambridge,org/dictionary/english/sociability.

Chickering, A.W. (1969). Education and identity. San Francisco: Jossey-Bass.

Elegbeleye, O.S. (2008). Sociability scale. Ile-Ife: Adeleye Press.

Irfan, M. \& Shabana, N.K. (2012). Factors affecting students' academic performance. Global Journal of Management and Business Research, 12, 2249-4588

Kopfler, M.E. (2003). Effect of romantic relationships on academic performance. National Undergraduate Research Clearinghouse, 6.

Moyosola, J.A. (2013). Personality characteristics as predictors of academic performance of secondary school students. Mediterranean Journal of Social Sciences.

Paul, E.L. \& White, K.M. (1990). The development of intimate relationships in late adolescence. Adolescence 24, 375-400.

Ronco, L., Dianne, S., Edzel, T., Marivin, T. \& Steven, P. (2012). The effects of having relationship to the academic performance of CFAD students.

Shulman, S. \& Offer, K. (2001). Adolescent romantic relationships: A look from the future. Journal of Adolescence, 24, 337-351.

Simmel, G. (1950). The Sociology of George Simmel. Translated, edited and introduced by Kurt H. Wolff. London: The Free Press.

Umar, S.S., Shaib, I.O., Yakubu, N.A., \& Bada, O. (2010). The effect of social factors on students' academic performances in Nigerian tertiary institutions. Library Philosophy and Practice,222-258.

Wentzel, K.R. \& Asher, S.R. (1995). The academic lives of neglected, rejected, popular, and controversial children. Child Development, 66, 754-763.

Quatman, T., Sampson, K., Robinson, C. \& Watson, C.M. (2001). Academic, motivational and emotional correlates of adolescent dating. Genetic, Social, and General Psychology Monographs 127(2), 211-234.

Zimmer, G., Melanie J., Jessica S., \& Andrew C.W. (2001). Diverse aspects of dating: Associations with psychosocial functioning from early to middle adolescence. Journal of Adolescence 24, 313-336 